Article

\title{
The Accra Confession as Dangerous Memory: Reformed Ecclesiology, the Ecological Crisis, and the Problem of Catholicity
}

\author{
Henry S. Kuo ${ }^{1,2}$ (D) \\ 1 Graduate Theological Union, Berkeley, CA 94709, USA; hkuo@ses.gtu.edu \\ 2 First Chinese Presbyterian Church, New York, NY 10002, USA
}

Received: 20 April 2020; Accepted: 26 June 2020; Published: 30 June 2020

\begin{abstract}
This study presents the Accra Confession as a theological response to the ecological crisis from a Reformed perspective while also addressing its critical weakness, namely the problem of universality in both Reformed ecclesiology and global approaches to ecological destruction. Because of a fragile universality, both Reformed churches and global institutions find it difficult to agree on a concrete plan to address climate change. Theologically, this difficulty arrives not primarily from disagreement with the existence or causes of climate change but how Christian theological values translate concretely to acts of justice. This study proposes a way to ground these discussions on the concept of dangerous memory by resourcing the theology of Johann Baptist Metz. Dangerous memories allow stories of the suffering vanquished to be constitutive to the construction of caritas, which in turn serves as a suitable theological foundation for addressing differing approaches to engaging climate issues. Reading the Accra Confession as dangerous memory, then, provides a valuable resource to the Reformed community by allowing the testimonies of those affected adversely by climate change to substantially inform theological discourses on climate justice.
\end{abstract}

Keywords: Reformed theology; ecclesiology; climate change; critical theory; Johann Baptist Metz; Accra Confession; religion and the environment; dangerous memory; catholicity; ecotheology

\section{Introducing the Challenges of Universality in Church and Climate Change}

The engagement between religion and environment, specifically the ecological crisis the world is encountering, is a discussion that is timely, necessary, and increasingly urgent with each passing day. Within Christianity, theological and pastoral engagements with climate change are not new. St. John Paul II, in his message for the World Day of Peace in 1990, connected the pursuit of world peace to the criticality of humankind's respect for nature. As he emphasized,

When the ecological crisis is set within the broader context of the search for peace within society, we can understand better the importance of giving attention to what the earth and its atmosphere are telling us: namely, that there is an order in the universe which must be respected, and that the human person, endowed with the capability of choosing freely, has a grave responsibility to preserve this order for the well-being of future generations. I wish to repeat that the ecological crisis is a moral issue. (John Paul II 1990, §15)

The next year, the Orthodox Metropolitan Dimitrios Arhondonis was elected and enthroned as the Ecumenical Patriarch Bartholomew I of Constantinople. His predecessor, Patriarch Demetrios I, had published an encyclical on the preservation of creation in 1989, laying the groundwork for Orthodox theological reflection, prayer, and action on it. Bartholomew enthusiastically continued that work, convening summits and pan-Orthodox meetings addressing issues of the environment within 
a year after his enthronement (Chryssavgis 2007, pp. 9-10). The Ecumenical Patriarch's tireless and continuing advocacy on the protection and preservation of the environment earned him the nickname, "The Green Patriarch". Additionally, various Protestant leaders from a variety of denominations and traditions have called for Christians to engage on ecological issues. This article introduces, explicates, and engages how churches in the Reformed tradition - the tradition first articulated systematically by the 16th century Genevan reformer John Calvin and expounded by his theological descendants-have theologically responded as an ecclesial community to the theological and moral problems posed by climate change.

But efforts to deepen the discourse between environmental issues and Reformed theology run quickly into two challenges. First, what is the nature of a Reformed ecclesiology? Or, to put it bluntly, is there $a$ Reformed ecclesiology to begin with? Reformed Christians may quickly answer that all Reformed ecclesiologies are confessional. In the face of opposition, evil, and even death, for a church to be confessional means that it does not retreat from proclaiming to the world what is right and true, declaring instead that on this ground of faith or practice, we stand and cannot do otherwise-so help us God. ${ }^{1}$ The visible expression of that stance comes in the form of written confessional statements, or "confessions". Thus, this article presents one such confession-the Accra Confession-as a Reformed response to the ecological crisis. However, despite the Confession's adoption by the World Communion of Reformed Churches (WCRC), it is not binding on all member churches because Reformed ecclesiologies are oriented "from below". That is, individual churches or ecclesial bodies do not have the authority to compel other churches to act or ascribe to doctrines against their informed consciences. But therein lies a fundamental ecclesiological problem: in the presence of a diversity of conscience-led confessions and interpretations of doctrinal and ethical matters, how do churches agree on problems demanding a unified response? How do churches converge on ways forward on deep disagreements without splintering? These questions will be revisited shortly as we make way on laying out the problematic in this study.

The second challenge is to articulate the nature of and contexts surrounding the ecological crisis. This is not to say that climate change is not a real and serious problem, but that the nature of the problem is not simply scientific. If that were the case, then reversing environmental destruction would simply be a question of when technological advances would catch up to the addressing the challenge. The United Nations' climate change conferences would have been narrowly focused on sharing technological improvements or proposing new ones to combat ecological destruction. In truth and reality, however, the nature of the ecological crisis is multifaceted and touches upon an intersection of human histories and systems. Any effective and comprehensive response to the human dismantling of ecological balance requires exegeting and interrogating global consumption habits, investment strategies, historical contexts, and a myriad of other intersectional considerations. Hence, religious and theological considerations matter to the climate crisis because such inquiries assist in that questioning of at least some of the elements which contribute to the problem at hand and, hopefully, provide resources for the necessary resistance and praxis. This reality, however, compounds the complexity of the matter and, therefore, generates a multiplicity of approaches to tackling ecological destruction.

The two aforementioned challenges-the act of confessing and addressing the multifaceted nature of ecological destruction-are more fragile than they appear. My core argument in this article is that at the root of both challenges is the problem of universality. In Christian theology, the question of universality is encapsulated by the word "catholicity" which, according to the Nicene Creed, is the third mark of the church. Yet, this is hardly more helpful because what is universal is subject to various interpretations. What about the church is universal? How are those things that are

1 This phrase is based on a saying commonly attributed to Martin Luther: "Here I stand; I cannot do otherwise. So help me God." Although the exact quote was not recorded to have been said by him at the conclusion of his testimony at the Imperial Diet of Worms, it nonetheless became a concise encapsulation of the theological sentiments behind the Protestant Reformation. 
universal in the church actualized in local contexts? What is the relationship between universality, diversity, and uniformity? Many schisms that have torn apart the church were rooted in the many sometimes-divergent answers to these questions. A similar conundrum exists in articulating the challenge of climate change. Agreement on the extent of ecological destruction and its causes, as well as constructive proposals to minimize or reverse the damage, proves elusive as scientific realities and urgencies clash and often surrender to abundantly-capitalized political, economic, and other powerful interests. As we will discuss shortly, the United Nations' 2015 Paris Agreement was signed by 195 countries but lacks any politically binding target or other meaningful enforcement mechanism after tremendous resistance from the largest polluting nations, such as China, the United States, and India, effectively guaranteeing no real consequences for failing to abide by the Agreement.

Are we, then, to resign to the hopelessness of climate inaction or any Christian response to it on the account of the diversity of global and Christian perspectives on the matter? Preferably not. Ironing out differences and pursuing uniformity of perspectives is a tall order when people from different tribes, nations, and cultures interpret the same problem—church or climate-from their localized lenses. What is lacking is an atmosphere of patient and reasoned consideration that comes when different peoples share a certain Verbindlichkeit or "binding-ness" that transcends the many diversities in human communities. My constructive proposal is to draw on the work of the late theologian Johann Baptist Metz to show how considering the Accra Confession as dangerous memory can provide resources for churches of Reformed persuasions to concretely and charitably engage climate change together as a community.

\section{The Double-Bind of the United Nations' Climate Response Efforts}

Efforts to negotiate an effective global agreement on combating climate change are not new. In 1992, the UN convened a conference- the Earth Summit-specifically to provide an international forum for discussing issues pertaining to sustainable development such as finding alternatives to global reliance on fossil fuels or addressing water supply and demand problems. The motivations for the Conference, however, were warnings by scientists regarding how large increases in human-made greenhouse gases are the strongest contributors to global warming beyond what could be attributed to nature (Boisson de Chazournes 2008b, p. 1). The Summit led to the UN Framework Convention on Climate Change (UNFCCC), a treaty which provided signatory states with a set of general and specific commitments. One of the more notable commitments was reserved for developed countries, which accounted for most of the world's greenhouse emissions. The nations involved committed to reduce greenhouse emissions and report their progress to subsequent Conferences. Wealthier developed nations also committed to providing funding and other resources to assist developing and vulnerable nations promote technologies and alternative sources of energy which would not contribute to increased greenhouse emissions (Boisson de Chazournes 2008b, p. 3).

Yet, as the international law expert Laurence Boisson de Chazournes observes, even though the Summit's importance was grounded on scientific concerns over a universal problem, there were nonetheless diversities of understanding and interests. An international climate conference in Geneva two years prior, for example, revealed the existence of a "North-South" divide when it came to how people in different countries regarded climate change. The "northern" and more developed countries tended to understand climate change as a predominately technical problem that belongs in scientific and environmental discussions while "southern" and less developed countries generally connected climate change efforts with economic development, particularly the fight against poverty (Boisson de Chazournes 2008b, pp. 1-2). Moreover, underlying national interests conspired to whittle away the sharp edges of the Convention. While the OECD countries had no qualms about reducing the emissions of greenhouse gases, they did not agree on how much they should be reduced. In particular, the United States resisted being subjected to any obligation for emissions reduction. At the same time, representatives from developing countries were unwilling to allow possible obligations to combat climate change inhibit economic development. The oil-exporting OPEC countries whose economies 
were hugely dependent on oil exports were exceedingly worried that the wider effort to reduce greenhouse emissions would negatively impact their national bottom lines. These often-competing interests essentially watered down the Convention such that "when the Governments adopted the UNFCCC, they already knew that its general and special commitments would not suffice to seriously tackle climate change" (Boisson de Chazournes 2008b, p. 4).

Thus, over the next five years, negotiations between many countries sought to find a way forward in strengthening the Convention's commitments. These efforts culminated in the drafting and ratification of the Kyoto Protocol. Nonetheless, the same national and party interests that defanged the strength of the Convention continued to persist and, in some ways, further complicated negotiations. As Boisson de Chazournes reports, the United States broadly agreed to the goal of stabilizing greenhouse emissions but resisted any reductions of it while European nations favored limiting emissions of up to 15 percent on the condition that the United States committed to that limitation as well. At the same time, developing nations were not about to let developed nations off the hook but were extremely hesitant to have commitments imposed upon them, especially since many of them were unwilling to sacrifice economic growth in reducing emissions (Boisson de Chazournes 2008a, pp. 1-2). While the Kyoto Protocol expanded the UNFCCC's provisions on some matters, such as introducing market-based mechanisms to enable countries reduce emissions with an eye to cost-effectiveness and efficiency, the emission reduction targets were only temporary and would end in 2012. Additionally, the Protocol did not come with new commitments for developing nations, even though countries like China and India were rapidly industrializing but were exempted (Boisson de Chazournes 2008a, p. 4). Even so, while the United States signed on to the Protocol, the incoming President George W. Bush already had significant misgivings about the exemptions for industrializing countries and its impact on the U.S. economy. Thus, early in his presidency, he already directed the Department of State to investigate ways for backing out of the Protocol legally and refused to ratify it (Urpelainen and Graaf 2018, p. 1). While further meetings would iron out the details, when negotiators from 178 countries met in Bonn, Germany in 2001 to agree to adopt the Protocol, the United States did not participate, raising questions about whether it could be effectively implemented. And even so, a few years after the Kyoto Protocol took effect in 2005, Canada withdrew, noting that the goals were difficult to meet without the commitment of the United States and China, the latter two of which were the two largest contributors of greenhouse gases by that time. Even so, the Kyoto Protocol was temporary and scheduled to end in 2012, which meant that there was little incentive to hold strongly to the Protocol's agreements when the outcome of the next negotiating stage was rather nebulous. Indeed, as Scott Barrett noted, the Protocol was envisioned to be a "first step" to a more ambitious successor agreement (Barrett 2008, p. 241). Yet, when an effort to draft a succeeding treaty came in 2009 at the Copenhagen Summit (COP15), conference delegates were relentlessly deadlocked over the distribution of burden for climate change between countries, leading to speculations that the talks were in disarray. In the end, only a non-binding political statement-the Copenhagen Accords—was embarrassingly agreed upon.

Finally, on 30 November 2015, delegates from 196 state parties gathered in Le Bourget, on the outskirts of Paris, in a second attempt to negotiate a stronger international agreement to combat climate change. The Paris Conference met in an atmosphere where public demonstrations in favor of a stronger agreement were organized. A few months before, Pope Francis published his encyclical, Laudato Si', which was well-received by the public and generated much discussion both inside and outside of Christian circles. Thus, expectations were high for an ambitious conference that would achieve a universal climate agreement. Unfortunately, as the conference continued, the same fault lines from previous Conferences persisted with highly industrialized nations, including China, being resistant to binding and enforceable emissions targets and countries vulnerable to climate change pushing for the opposite. Hence, the fact that an agreement rather than news of deadlock came out of the Paris Conference was notable in and of itself. However, the Agreement's text gave rise to criticisms of its goals being difficult to enforce and not ambitious enough. Signatories committed to a goal of limiting global warming to below 2 degrees Celsius when compared to pre-industrial levels, and for attaining 
net zero greenhouse emissions in the latter half of the 21st century. But, as Cary Coglianese describes, the Agreement contains significant structural limitations pertaining to governance and enforcement:

[The Agreement's] basic scheme-sometimes described by analysts as "pledge and review"depends on each nation declaring its own climate mitigation goals and developing plans to achieve those goals through domestic policy interventions. The Agreement itself does not impose any substantive requirement that countries reduce their greenhouse gas emissions. Instead, it imposes an obligation that countries announce their own "nationally determined contributions" to the global effort to reduce emissions. It does not make nations' self-determined emission-reduction goals legally bind. (Coglianese 2019, p. 141)

The limitations of the Paris Agreement raised further questions in 2017 when Donald Trump became President of the United States. Supported in part by well-heeled fossil fuel and corporate interests, and citizenry who were suspicious of climate science, he announced the United States' withdrawal from the Paris Agreement on the basis of the latter's threat to the American economy. The formal announcement was made on 4 November 2019, the earliest date the U.S. could do so according to the Agreement, and will be in effect on that date in 2020. Other signatory nations have criticized the decision and vowed to push forward on implementing the Agreement without U.S. involvement, although the Agreement's success is still too early to ascertain.

What I have provided is a flyover of the recent history of UN climate change efforts, but the concern in this study is not the history but the problem underlying universal efforts to addressing climate change, namely the problem of diverse points of view. The problem is a double-bind. Diversity of views and interpretations on many matters exists because different peoples bring to the negotiating table their epistemological and cultural backgrounds, as well as their unique experiences on the subject. Delegates, representing leaders who were accountable to different constituencies and interests, could hardly be expected not to voice their nations' short-term concerns, even if those ran counter to the goal of mitigating climate change. In fact, politicians in many of the largest polluting nations regularly confront electorates, many of whom regard climate change as not urgent a priority compared to maintaining economic growth. These competing priorities were at play throughout the negotiation efforts as the urgency of reducing greenhouse emissions in order to avoid a calamitous global future clashed vehemently with the near-term economic needs or political concerns of particular negotiating countries. The United States, for example, negotiated against more ambitious goals so that it would not require ratification by the Republican-controlled Senate, where it would in all likelihood have failed (Urpelainen and Graaf 2018, p. 8). Major oil-exporting countries like Saudi Arabia, whose economies are heavily reliant on the commerce of fossil fuels, would most likely bear the brunt of the negative consequences of climate change treaties. Yet, for many small island-nations whose existences in the near-term are threatened by rising water levels, climate change is an urgent matter demanding ambitious solutions. On top of it all, every delegate recognized that confronting the climate crisis is important not just for their countries' futures, but for the world's future. Such a universal problem demands the cooperation and action of all countries. A win-win scenario for all parties is impossible; thus, the double-bind. Hence, it should not be surprising that what came out of the conference would not please all parties.

Delegates to the Paris Conference were cognizant of the double-bind, especially since the dynamic of competing interests and interpretations deadlocked the Copenhagen Conference. Thus, the Conference leaders adopted a different diplomatic strategy. As Rafael Leal-Arcas and Antonio Morelli observe, previous summits have adopted a top-down negotiating approach, with the problem of climate change posed, environmental scientists providing best solutions to the problem, and delegates then trying to converge on a binding statement to address them (Leal-Arcas and Morelli 2018, pp. 14-15). The Paris Conference shifted to an approach "from below" where the emphasis was placed not on a universal conformation to a specific and globally-agreed-upon target emissions level, but on a voluntary approach in which individual countries assessed their own situations with respect to climate change and committed to their own climate mitigation goals, implementing domestic strategies to 
achieve them. "Enforcement" comes, not from the United Nations or a supra-national authority, but from member states who hold each other accountable to their own goals through diplomatic pressure (Coglianese 2019, p. 141). While this strategy avoided a deadlock in which emissions-heavy countries fought against being bound to fixed targets while vulnerable countries fought for stringent targets, it remains to be seen as to whether self-assessed climate goals would be effective against climate change and whether accountability can be effective when most of the emissions-heavy countries carry significant economic and geopolitical power. Indeed, the U.S.'s pledge involved cutting $\mathrm{CO}_{2}$ emissions from power plants by $32 \%$ below 2005 levels by 2030 , which was criticized as being the least ambitious (Urpelainen and Graaf 2018, p. 4).

In light of our historical survey and assessment of the UN climate change efforts, the issues for this study are twofold. First, the contention I will unfurl slowly is that Reformed approaches to climate change contain similar dynamics to the UN climate conferences in which a diversity of local experiences, interests, and interpretations of climate change and its possible solutions conspire against a bold solution to the crisis. But second, despite the diversity of theological and moral perspectives circulating among Christians in the Reformed tradition, theological resources are available to navigate a path through the differences in points of view that allows for some degree of convergence to emerge. That is, approaching concrete and workable solutions to climate destruction "from below" does not mean convergence is not possible, but that a common theological method is necessary so that diversity becomes a constructive resource and not an impediment for environmental justice. Before addressing this point, however, we turn first to the Reformed theological response to the climate crisis: the Accra Confession.

\section{The Accra Confession}

Discussions at an institutional and global level regarding the Reformed churches' theological response to economic injustice and environmental degradation generally began in the early 20th century as the World Alliance of Reformed Churches (WARC) took up social and political concerns that have arisen. As Patricia Sheerattan-Bisnauth recounted,

Since the 1920s, the alliance has been actively involved in addressing social issues, such as the adverse consequences of industrialization. WARC has criticized unjust social systems and promoted a cooperative society as a model for equity in the sharing of resources. The alliance led protest actions against the treatment of Native Americans and called upon its member churches to confess Nazi crimes against the Jews during the Holocaust (the Barmen Declaration, 1934). (Sheerattan-Bisnauth 2008, p. 237)

The formal journey towards the Accra Confession began in 1995 with the Southern African Alliance of Reformed Churches' organizing of a consultation on Reformed faith and economic justice in Kitwe, Zambia. The consultation listened to testimonies and laments of suffering and despair from various African communities and how many hardships resulted from the continuing abuse of African peoples as cheap labor and African resources as cheap resources, as well as the relentless imposition of unfettered capitalism and the economic force of large multinational corporations that upset fragile communities that had little time to respond. Importantly, the Kitwe consultation named "the global economy" as a theological challenge, having displaced God's sovereignty over all creation. Hence, with an upcoming General Council meeting in mind, the consultation encouraged additional considerations to undergo the processes necessary to declare economic injustice a confessional matter (Sheerattan-Bisnauth 2008, pp. 238-239).

In 1997, the WARC General Council convened in Debrecen, Hungary with the theme, "Break the Chains of Injustice." But already in many of the presentations, there were entreaties from local churches to attend not merely to the economic dimensions of the injustice, but also to the intersectionality of various other injustices that their communities routinely encountered and struggled with, including environmental destruction. The WARC General Secretary Milan Opočenský, for instance, began his 
reflections by referencing the 1986 Confession of Belhar, which was written by the Dutch Reformed Mission Church of South Africa in declaring apartheid and racial separation as sinful, noting how it was a local declaration that, at the same time, was "an invitation and a challenge to all churches, especially in the Reformed family, to concur in the act of confessing" the sinfulness of racial separation (Opočenský 1997, pp. 73-74). But he continued by musing that, while confessing racism as sin and heresy was an important theological step to take officially in light of racism's pernicious history in the past several decades, additional sins pertaining to economic and environmental matters may also demand similar confessional stances. Delegates to the Council concluded with a call to engage in a processus confessionis, in which churches discerned the confessional importance of economic and environmental justice in Reformed faith, worship, and witness.

Several subsequent consultations would deepen the discernment, preparing WARC for its 24th General Council meeting, which was held in Accra, Ghana in 2004 and themed "That All May Have Life in Fullness." By then, other Protestant bodies had already issued faith declarations or particular stances on matters of economic injustice, globalization, and environmental degradation. The Lutheran World Federation, for example, began their process for discerning the matter in 2000 (Park 2004, p. 193). In his opening presidential address to the General Council, the theologian Choan-Seng Song deconstructed the idea of "having life in fullness" and its implications for churches to create conditions to facilitate it. Song's analysis could perhaps be distilled into two pastoral dimensions: healing and outreach. Recognizing that Christian expansion throughout history has often introduced violence, disruptions, and in some cases, destruction to local communities, he exhorted churches not only to commit passionately to the healing and reconstruction of local communities as part of their mission in Christ, but also to be patient and careful listeners of peoples in those communities (Song 2004, pp. 106-109). But for churches to function as nexuses for encouraging the fullness of life in their local communities requires them to be agents of healing and evangelization, two critical factors that ground Christian missions of justice in the world today.

What this meant concretely was made clearer when the Council's delegates visited the "slave castles" of Elmina and Cape Coast as part of their meetings on 3 August 2004. It clearly was a very moving experience for many of the delegates. As the Council recounted,

Our most moving and memorable moments [of the Council] came from our visit to Elmina and Cape Coast, two "castles on the Coast of Ghana that held those who had been captured into slavery, as they suffered in dungeons waiting for slave ships that would take them to unknown lands and destinies. Over brutal centuries, 15 million African slaves were transported to the Americas, and millions more were captured and died. On this trade in humans as commodities, wealth in Europe was built. Through their labor, sweat, suffering, intelligence and creativity, the wealth of the Americas was developed. (World Alliance of Reformed Churches 2004b)

Seeing the slave holding pens with their own eyes enabled the delegates to viscerally piece together the intersecting ways in which global trade, colonization, and the suffering of humanity and creation feed into each other. With Reformed bodies and other Churches pushing forward on this theological and moral problem in their corporate reflections, the delegates discerned the necessity to move from processus confessionis to status confessionis. The Accra Confession was drafted and refined throughout the Council meetings and by its conclusion, the Confession was adopted and reaffirmed by the General Council of the renamed World Communion of Reformed Churches (WCRC).

The Confession contains four sections. ${ }^{2}$ The first is an introduction that briefly traces the history of meetings and consultations that led up to the Confession, a history which we have just traversed (Accra, 1-4). The second section, entitled "Reading the Signs of the Times", endeavors to establish

2 To reference specific sections, I will cite the Confession by their numbered paragraphs, e.g., (Accra, 1-42). 
the confessing context that necessitated the Confession, the summary of which could be found at the beginning statements: "We see a dramatic convergence between the suffering of the people and the damage done to the rest of creation. The signs of the times have become more alarming and must be interpreted. The root causes of massive threats to life are above all the production of an unjust economic system defended and protected by political and military might" (Accra, 5-6). The economic system in question is "neoliberal economic globalization", which is understood as having four critical characteristics: [1] the encouragement of unrestrained competition and consumerism; [2] the moral understanding that wealth accumulation and private property ownership convey no social obligation; [3] capital speculation, market liberalization, the emphasis on deregulation and privatization of public utilities and national resources, unrestricted access for foreign investments and capital, aided by lower taxes and similar political policies; and [4] the social primacy of economic growth and capital accumulation over obligations such as the protection of the poor and weak, trade unions, and interpersonal relationships (Accra, 9). The Confession's writers were concerned that such an economic system was quickly becoming an idolatry in which it, alone, is the most salvific political-economic system that promises wealth and human flourishing when, in reality, the wealth of nations are often built on the backs of the poor and marginalized, an arrangement enforced by powerful nations that command extensive diplomatic, legal, and military influence (Accra, 10-14).

The third section is the confessing heart of the statement, which also makes it the most controversial one. In it, the Confession issues several articles of faith that are universal—that is, catholic - throughout Christian churches that are accompanied by the requisite theological response. Given how economic justice interfaces inexorably with climate justice, significant focus is given to the doctrine of God's sovereignty, a critical facet in Reformed theology. God's sovereign lordship over all creation carries a variety of implications, one of which is that God does not suffer to be enlisted into human agendas. In his Institutes of the Christian Religion, John Calvin reminds readers that "God ever remains like [Godself] and is not a specter or phantasm to be transformed according to anyone's whim." (Calvin 2006, Institutes I.4.3) Instead, humanity and its socio-political structures are always subject to God's critique, as attested to in Scripture and the church's traditions. Hence, drawing from Scripture's testament of a God who claimed eminent ownership over the world, covenanted with humanity never to destroy the earth after the Flood (the Noahic Covenant), and relentlessly paid special attention to the poor, the Accra Confession rejects socio-political systems (in particular unfettered market or totalitarian planned economies) that deny subjectivity to the poor and marginalized. Additionally, it forswears irresponsible consumerism and selfish wealth accumulation to the detriment of the Earth and its inhabitants, as well as worldviews that work against the poor and against the proper stewardship of creation (Accra, 17-34).

Accra's structure in this third section is critical because what it endeavors to confess against is not merely an economic arrangemenft or political structure, but neoliberal capitalism and Empire as a theological and ethical system. Ulrich Möller curiously argues that Accra does not reject the political-economic-military system as a false doctrine or heretical teaching that denies God's sovereignty over all creation (Möller 2005, p. 209) His argument may hold based on the Confession's text alone, but only if one maintained a distinction between rejecting false doctrine and rejecting any teaching, theology, or ecclesial practice. Indeed, Möller concurs but does not explain why such a distinction should exist. In fact, some theological reflections from important Reformed thinkers problematized such a distinction. The influential Swiss theologian Karl Barth, for example, raised red flags over the persistence of what he called "lordless powers", a human-made totalizing and destructive reality. As he describes it, "We have described this adversary first as the great disorder that controls and characterizes the state and course of human things. It is the human unrighteousness that contradicts and opposes the salutary order and righteousness of God." (Barth 2017, p. 299) And he continues later to name and denounce Empire — which he states is "always inhuman as such"—and how it can be found in various forms of political manifestations, including democratic, nationalistic, or social 
ideas (Barth 2017, p. 308) This would be accompanied by his denouncement of Mammon, where he writes that,

[Humanity's] relationship to God and neighbor would have to be different if [they] were not mildly or wildly fascinated by [money]. It is clear that Mammon in the form of money, which stirs and excites the speculative imagination in a very different way from barns and their contents, can be and is much more intensive Mammon, the lordless power of material resources that holds absolute sway over man and men and humanity ... Money is a flexible but powerful instrument which, supposedly handled by man, in reality follows its own law. (Barth 2017, p. 313)

Barth is certainly not alone. Ofelia Ortega extends Barth's analysis by forwarding a definition of Empire as a "colonization of subjectivity." (Ortega 2009) More than being mere ideologies, the values and vices of neoliberalism, militarism, and atomistic individuality become core to human existence in society. Hence, contrary to Möller's argument, Accra does reject certain political-economic systems, not because they are per se evil but, like any errant doctrine or harmful ideology, they reconfigure human relationships in ways that excuse and even encourage disregard for human flourishing and ecological preservation.

The final section of the Confession concludes with an exhortation for local churches to interpret and implement the Confession in their local contexts, while also working with other Christian communions and those of other faiths to work towards economic justice and environmental preservation (Accra, 37-42).

The Accra Confession is arguably the first Reformed confessional statement that explicitly addresses economic justice and ecological destruction. To be sure, much of the Confession's text focuses on the theological imperative for Christians to confess against unjust economic systems, with concerns regarding environmental injustice being an outworking of that confessing since, per the discussions and testimonies from the ground at Accra, economic injustices and crushing poverty in many African communities could not be separated from theologies of the land and environmental stewardship. Even so, despite the non-exclusive focus on climate change and ecological protection, the Confession is at least important for being a substantial starting point for continuing Reformed conversations and reflections on the church's responsibilities for working towards a more balanced and wholesome relationship between humanity and all created order. That being said, it is not a perfect statement and the few problems in it limit its universal effectiveness. The Confession states that "by confessing our faith together, we covenant in obedience to God's will as an act of faithfulness in mutual solidarity and in accountable relationships" (Accra, 37). But, like how the problems of diverse negotiating stances and particular interests plagued the UN's efforts for a universal climate treaty, the needed solidarity and accountability for Reformed churches to get behind the issue as one could only be forged if there was a general agreement on how the signs of the times were to be interpreted and the appropriate theological responses to those interpretations discerned. Such agreement did not happen with Accra. As Amy Reynolds describes, global North church bodies, including the Presbyterian Church (U.S.A.), were resistant to the Confession's articulation and condemnation of globalization and neoliberal capitalism (Reynolds 2014, pp. 80-81). One reason is, naturally, that nobody desires to be on the receiving end of criticism. Thus, some resistance should be expected.

Nonetheless, as Reynolds continues, critiques in the Presbyterian Church (U.S.A.) regarding matters of injustice usually were not immediate, eventually arising slowly, percolating through various congregations, presbyteries, and synods before becoming national questions at the General Assembly. Additionally, the critiques never implicated the United States by name or identified it as a key node within a global network of injustices. Such a rhetorical strategy names the problem as an abstract issue and avoids concretizing the matter. Concretization, after all, demands a practical response. How the response is framed and conveyed (or lack thereof) unveils layers of power, privilege, and more importantly, a local church body's self-understanding of who God is and how God relates to their neighbors. Tied up inextricably with the lack of a Verbindlichkeit between different church bodies of the 
same theological tradition attests to issues of asymmetric power and privilege. Wealthier Presbyterian bodies can defang the Accra Confession by weaponizing nuance and economic theory to discredit or dull the critiques posed by suffering peoples in less wealthier bodies while the former maintain their privilege; this perspective also subversively infantilizes suffering peoples and avoids highlighting how the latter continues to bear the consequences of economic inequality and environmental destruction.

But the lack of a binding quality to Reformed intra-ecclesial relations is also attributable to the nature of confessional statements themselves which, in turn, speak to the problem of universalizing principles across a variety of cultural and experiential landscapes. Reformed confessions are not universal; no one statement encompasses the entirety and diversity of the Reformed tradition. This differs from some Christian traditions, such as Roman Catholicism, in which an ecclesiastical administrative structure and a body of doctrinal teachings and liturgical practices, among others, are universal across Catholic churches across the world, even though some leeway is allowed for contextualization into local contexts. To use another example, one of the key ways the Lutheran tradition demonstrates its catholicity is the Book of Concord or Concordia, a compilation of documents that are catholic to all Lutheran churches throughout the world. Reformed confessions, however, usually speak to local challenges, connecting them to truths that are universal to the Christian tradition. Thus, Eduardus Van der Borght is right to suggest that all the confessions, taken as a whole, constitute visible symbols of Reformed catholicity (Van der Borght 2008, p. 188). But what that also means is that no one Reformed body or church possesses the authority to compel another to confess matters a certain way. Catholicity in the Reformed imagination, then, is achieved through persuading other churches to receive confessions and its lessons.

This is much easier said than done, which is why Dirk Smit is right to observe how a significant problem of the Accra Confession is its reception (Smit 2009, p. 182). How could, for instance, American Presbyterians receive the testimony of Presbyterians in Ghana that American consumption habits adversely affect the environment and local ecosystems in Ghana which, in turn, negatively impact their own lives and well-being? What we have is a problem of shallow catholicity where local church bodies share extremely thin and fragile connections to other church bodies. Such superficial catholicity provides a convenient alibi for maintaining the economic, military, and political privileges and powers that comfortably insulate privileged Christian peoples from any direct involvement in matters of environmental stewardship and economic justice. The necessary via resistentiae requires us to articulate a deep catholic sensibility that not only recognizes the important connections all creatures have with each other, but also makes it possible to create networks of accountability which allow all God's creatures and the environment they live in to flourish and, indeed, have fullness of life. My suggestion to begin articulating this vision of deep catholicity requires expositing the concept of dangerous memory, a subject we turn to presently.

\section{The Accra Confession as Dangerous Memory}

The Ewe-mina peoples of Benin, Ghana, and Togo have a proverb that roughly goes, "Until the lion has its own storyteller, the hunter will always have the best part of the story". The proverb points presciently at the importance place power occupies in shaping the narration of human experiences. Such a sentiment lies at the root of Walter Benjamin's ruminations in his controversial "Theses on the Philosophy of History", and connects to the concept of dangerous memory. My contention is that reading the Accra Confession as dangerous memory provides a theological challenge to Reformed churches to regard the testimonies of the suffering churches as interruptions to predominant economic, environmental, and political narratives that they have taken as normative. Disrupting such normativity, in turn, allows the Confession to be an invitation for Reformed churches to open themselves to embody authentic caritas, as opposed to a cupiditas masquerading as caritas.

Benjamin's "weak" messianic philosophy of history begins by illuminating the theological animation behind the historical materialist project. Theology matters for history because it is what prevents history from being merely a chronicling of discrete events, which excises any responsibility of 
the present for past injustice and suffering. Thus, he writes in his third thesis that "only a redeemed mankind receives the fullness of its past-which is to say, only for a redeemed mankind has its past become citable in all its moments" (Benjamin 2007, p. 254). What humanity must contend with, to use the words of the Ewe-mina, are historical narratives conditioned by the victorious hunters with little interest in remembering the complete and nuanced story of the vanquished hunted. Such historical consciousness constitutes what Benjamin calls "universal history" which is homogeneously and progressively constructed (Benjamin 2007, pp. 262-263).

The vanquished, however, are not entirely deprived of a voice. "They have retroactive voice", writes Benjamin in his fourth thesis, "and will constantly call in question every victory, past and present, of the rulers." (Benjamin 2007, p. 255) Indeed, their voice presents a challenge and responsibility for the present: a chance to fight in solidarity with the marginalized and suffering past. What this means for history is that historical truth or reality is better understood as a constellation of interruptive memories, images of the vanquished past that "flits by", to be seized "as it flashes up at a moment of danger" (Benjamin 2007, p. 255). Such memories endanger received narratives and traditions, giving them a complexity and undermining their supposed stability so that history does not have a chance of becoming controlled by the victors. Marsha Hewitt, citing Theses III and XVII, summarizes it aptly,

The "fullness of [the] past" is not recovered by trying to integrate it into the flow of historical continuity, where it becomes absorbed by the totalizing power of master narratives (the narratives of the masters and victors) and thus falsified; rather, redemption becomes possible in arresting the historical continuum by blasting "a specific era out of the homogeneous course of history-blasting a specific life out of the era or a specific work out of the lifework." The "reawakening" of the past occurs through a cognitive shock that results when the horrors of past brutality and exploitation are made visible. (Hewitt 1994, p. 78)

Benjamin's messianic conception of historical understanding, then, is a weak messianism insofar as he situates messianism not in a person but in an idea or image. Redemption arrives when the historical materialist seizes on interruptive memories, memories that trouble prevailing historical narratives, thereby endangering them. Dangerous memories, therefore, are pregnant with possibilities for revolution and liberation in the present and future.

The theologian Johann Baptist Metz seized on this concept and gave it an explicitly Christian-theological reconstruction. Just as Benjamin's historical method was grounded in concrete images or narratives that "flash up" in moments of danger, the Münster priest-scholar's theological method draws on autobiography and narrative. As he describes it, "theology, precisely as a politically sensitive theology, takes on the traits of biography; but the orientation toward the subject, toward the countenance, toward the function-in-the-face-of, bestows on theology traits of narrative and memory" (Metz 1999, p. 136). The stories of silenced voices and vanquished lives create a responsibility that theologians today must attend to, not only as a constitutive element of Christian witness, but also as an obligation to remember the future in the now. Indeed, as John Marsden phrases it, "within this retrieval the power of narrative is crucial, since only the telling of the Christian story of subversive hope in solidarity with the meek of the earth has the performative power to interrupt the enclosed oppressiveness and a banality of the present" (Marsden 2012, p. 445).

An example from Metz is instructive. Metz recalls two poignant experiences that proved to be formative for his theological work. The first came from his time as a sixteen-year-old forced conscript in the Nazi Army during World War II. While he was sent to relay a message to his battalion's headquarters, Allied forces decimated his company and left no survivors. As he recalled poignantly, when he returned and saw the faces of his dead comrades, "I remember nothing but a soundless cry ... Over and over again, just this silent cry!" (Ashley 2003, p. 35) The second and more general memory concerned the Holocaust, which he named "Auschwitz." As Metz's academic career developed in the ruins and subsequent reconstruction of post-War Germany (the Wiederaufbau), he became perturbed by the focus on rebuilding the nation without any serious consideration to living with the memory of Auschwitz, without any engagement with what it means to live in Germany or be German when 
Auschwitz is an inescapable part of German history. Here, Metz meshes with Benjamin's philosophy of history:

At the outset, one must take into account that the catastrophe of Auschwitz, precisely because of its uniqueness, acquires a provocative character. This catastrophe cannot be integrated into the history which we usually talk about in our different types of modern theological hermeneutics ... The catastrophe of Auschwitz directs theology away from the singular of "history" and to the plural of "histories of sufferings" which cannot be idealistically explained but rather can only be remembered with a practical intention. (Metz 1999, p. 139)

In both of these memories, Metz worries that the rhetoric of economic growth and social progress has muffled any serious consideration and remembering of the suffering experienced during the war, and more generally, that such rhetoric has generated resistance to remembering narratives of suffering. "In contemporary life", Metz writes, "there is a kind of 'spell' (Bann) or 'blind spot' (Verblendungszusammenhang) that prevents or distorts insight into the primordial cognitive and practical role of suffering" (Metz 2007, p. 106). He directed his particular concern towards German post-War theology, noting how eminent theologians such as his doktorvater Karl Rahner, the Reformed theologian Jürgen Moltmann, and the Lutheran theologian Wolfhart Pannenberg have demonstrated a resistance to directly engage the memory of Auschwitz. To remember Auschwitz as dangerous memory-that is, a remembering with a practical intention-interrupts "history" in a way that produces the impetus for praxis and witness today. Hence, remembering dangerous memories disabuses Christians from inaction towards injustice or replicating systems of the status quo. Instead, it provides the theological foundation for daring new ways of being human communities and remembering a future that redeems the voices of those silenced by injustice.

But where Walter Benjamin grounded his philosophy of history on a "weak" messianism of interruptive images and memories, Metz's theology centered on a concrete memory. Metz writes that "Christian faith articulates itself as a memoria passionis, mortis, et resurrectionis Jesu Christi" where "the memory of the crucified Lord stands at the heart of [the] faith, a specific memoria passionis, which forms the basis of the promise of a freedom that will come for everyone" (Metz 2007, p. 107). But despite the "strong" messianism of Metz's theology, there is an epistemological shakiness to locating dangerous memory in the biblical witness of Jesus Christ. The Münster theologian is aware of how humanity is liable to conditioning memory-work. That is, we are liable to cherry-pick narratives to suit our own purposes. The distinguished theologian Elizabeth Johnson, drawing on Metz's work in her feminist articulation of the communion of saints, rightly describes how dehumanization and enslavement is facilitated when a dominating power destroys the heritage, traditions, and ancestral memories of vanquished peoples, legalizing only the telling of "official" history. As she describes further,

... only a certain kind of memory functions this way. By refusing to engage the hard edges of suffering and struggle, memory that is simply nostalgia, bathing the past in a sentimental light, or memory that works as an anesthetic, bringing the challenge of the past into reconciling harmony with the misery of the present, loses its transforming power. But memory that dares to connect with the pain, the beauty, the defeat, the victory of love and freedom, and the unfinished agenda of those who went before acts like an incalculable visitation from the past that energizes persons. (Johnson 1998, p. 165)

Johnson puts her finger right on what makes dangerous memories so dangerous and at the same time subversively powerful. Dangerous memories encourage people today to dare history, to remember a future that confers at least some redemption to the muffled hopelessness and silenced despair of the past by remembering a future where the conditions of hopelessness and despair are liberated with love and joy. Such anamnestic solidarity with the silenced peoples of the past is what dares Christians in the present to imagine new ways of being church, new ways of promoting human flourishing and making communities whole. This is why Metz could summarize his ecclesiology by asserting that "the 
church must understand itself and prove itself as the public witness and bearer of a dangerous memory of freedom in the 'systems' of our emancipatory society" (Metz 2007, p. 88). To bear the dangerous memory of the Christ who suffered, died, and rose again is to testify to the possibility of resurrection after suffering and death. To remember piecemeal this memory, oftentimes by remembering Jesus's victory over death at the expense of his suffering, is to remember a partial and fragmented gospel.

For Metz, why Christians may embrace a fragmented gospel stems from the epistemological and religious crises resulting from the Enlightenment that also allows such a gospel to mesh well with the privatizing sensibilities of a neoliberal capitalist market economy. In such a Weltanschauung, church devolves into yet another commercial entity, supplying religious services that conform maximally to the spiritual tastes and preferences of its members. "Religion", as he writes, "became a 'private matter', which one 'makes use of' following criteria of cultural needs and sobriety, but which one really does not need (anymore) in order just to be a subject at all" (Metz 2007, p. 49). Dangerous memories interrupt the catholicization of privatized theology that often abstracts faith. For instance, in an earlier work, Metz pointedly questions whether Christians take their faith seriously, or whether they are merely believing in their faith. "Are we Christians", he challenges, "really changing our hearts, or do we just believe in a change of hearts and remain under the cloak of this belief in conversion basically unchanged? Are we living as disciples, or do we just believe in discipleship and, under the cloak of this belief in discipleship, continue in our old ways, the same unchanging ways?" (Metz 1981, p. 3). Theology that truly matters is not merely an individual assent to conjectural doctrines but demands that a community of faith take praxis seriously, which is what makes dangerous memories so subversive and liberative for society.

These strands of Metz's theological insights converge in their application to dogmatic or confessional statements of faith, such as the Accra Confession. At this point, our reflections return to our considerations on Reformed theology and ecological justice. Here, I suggest that the Confession, when read as dangerous memories, interfaces with ecological justice in three ways. First, as a confessional statement, the Accra Confession is a doctrinal matrix of dangerous memories that opens possibilities for addressing the ecological crisis as a theological challenge in a variety of contexts. Second, it provides a hermeneutical baseline for the exercise of caritas across the Reformed tradition by situating the ground of its expression in the dangerous memories of those who suffer concretely from the negative consequences of the ecological crisis. Finally, the Accra Confession also illuminates the intersectionality of climate justice efforts, providing room not just for theologians but also for scientists, leaders, and other key conversation partners to engage with the quest for environmental justice.

To my first suggestion, if theology that matters is not an individualistic endeavor, then confessional statements can be helpful by instigating new interruptions of dangerous memories because they do not present individual but collective memories. Faith built on an individual's experience can be myopic and narrow. As Metz describes, confessional statements can "'force' me to call to mind in the present something that I cannot grasp and realize at all on the narrow basis of what I experience and perceive personally" (Metz 2007, p. 184). In this context, the Accra Confession can serve as dangerous memory for the church catholic in the Reformed tradition. If Accra represented an individual or even localized perspective, the argument could be made that it would be too narrow for it to be of catholic value. But because Accra was a statement that was considered, reflected on, and written by a committee from different contexts, its message that Christian faith demands ecological justice becomes not merely a local call, but an exhortation intended for universal application. The catholicity of that message is reflected in the language of the faith declarations in the Confession. What the Confession states as beliefs and their resulting praxical applications are not local articles of faith. For example, all Christians claiming to be orthodox to the church's apostolic teachings would believe "in God, Creator and Sustainer of all life, who calls us as partners in the creation and redemption of the world" (Accra, 17). This article of faith is shared throughout the global church, regardless of geographic or cultural differences, even if the implications of that belief may differ particularly. 
To my second point, the difficulty, as I have intimated earlier in this study, is not disagreement regarding those beliefs, but its applications. According to Accra, to use our previous example, the belief in God as Creator and Sustainer of life and God's sovereignty over all creation (Accra, 18) leads to a rejection of "the current world economic order imposed by global neoliberal capitalism and any other economic system, including absolute planned economies ... " (Accra, 19). This is not readily agreed upon, particularly by Christians who either benefit from neoliberal capitalism or many more who are accustomed to regard such a system as unquestionably beneficial for humankind. This is even more the case with questions of ecological justice. For many in the wealthier "Global North", the negative consequences of climate change do not easily impact their personal experiences in ways that make clear that a new way of living on earth is necessary.

Navigating these differing experiences requires a hermeneutical baseline. Here, I suggest that resourcing further back into the Reformed theological tradition, into the work of St. Augustine of Hippo, can prove useful. Love, or caritas, is a central theological concept that motivates much of Augustine's theology. Christian salvation is not merely an individualistic narrative between individuals and God, but an interweaving matrix connecting God's love for humanity (and vice versa) with the unfolding of salvation in history. As J. Warren Smith summarizes,

The Christian's one love of God and, by extension, the economy of salvation conditions her love to the many creaturely goods, most of all her neighbor and herself. She loves them because God loves them and she loves them as parts within the divine economy, each of which, knowingly or otherwise, contributes to the unfolding of the economy in history. To love one's neighbor and oneself within the context of salvation history is, for Augustine, to recognize the mutual dependence of self and neighbor. (Smith 2016, p. 15)

Caritas recognizes that Christians need each other to progress in faithfulness and righteousness. So critical was it to Augustine that he forwards it as being a foundational baseline for hermeneutics. While he was aware of the many ways in which the biblical text could be interpreted, he nonetheless maintained one principle: that Scripture "commands nothing but charity, or love, and censures nothing but cupidity, or greed, and that is the way it gives shape and form to human morals" (Augustine of Hippo 1996, DDC, III.10.15). Augustine's hermeneutical generosity accepts diversity so long as one's interpretive method encourages a universal caritas and discourages cupiditas, the latter of which is a failure to realize that God is the only proper object of humanity's enjoyment and, instead, misplaces love on things that are not of God. In his work on Augustine and the environment, Francisco Benzoni argues convincingly that this cupiditas, in the context of climate change, can be understood as "loving the world to death" (Benzoni 2004).

A caritas that matters is one that strives to uphold the dignity and worth of all peoples and created order, not just the peoples with whom we agree with. Thus, caritas needs to be inbroken by dangerous memories so that it cannot become subsumed into an alibi for political or economic fundamentalisms, enabling for a deeper conception of love that moves from a superficial unity of the same peoples to what Augustine calls "the unity that embraces all nations" (Augustine of Hippo 2004, Enarrationes, Psalm 147,19). Following this line of thought, the Accra Confession presents a dangerous memory for such Christians, allowing a universal declaration of faith to challenge ruling paradigms or social systems, the goodness of which are, quite literally, accepted by faith. It does this by presenting the experiences of those for whom the negative consequences of climate change are readily experienced. These memories present a challenge to Christians in the "Global North" by interrogating their preconceptions of caritas and open opportunities to stretch their ideas of Christian love in the direction of Jesus Christ's witness. Such witness, as the Accra Confession states, cannot ignore the well-being of the environment and of all creatures on Earth.

Finally, the Accra Confession interrupts any notion that ecological problems are not economic, or can be subsidiarized into functions of consumption or political calculi. Ecological problems are intersectional, requiring the involvement not just of environmental scientists, but of economists, international leaders, and theologians. The Confession endeavors to mirror this intersectionality to 
demonstrate that ecological, economic, and political problems are inextricably linked, and all of them are theological problems as well. Thus, it invites local Reformed churches to take the initiative and "continue to translate this confession into concrete actions both regionally and locally" as well as to "undertake the difficult and prophetic task of interpreting this confession to their local congregations" (Accra, 38-39). That being said, while there will be disagreements on how the doctrines that are catholic to all Reformed Christians translate concretely into acts of economic and ecological justice, negotiating all (dis)agreements would need to begin first from the dangerous memories of those who suffer from the ravages of climate change. The Accra Confession helpfully brings such memories to interrupt churches that are more distant from those experiences of suffering and pain, hopefully enlisting the diversity of resources in the Reformed body to resist the prolonging of the ecological crisis.

\section{Confessing a Reforming Ecological Sensibility and Universal Praxis}

This study has traversed across a diverse theological terrain, but at its base, it introduces a Reformed response to the ecological crisis, namely the Accra Confession. The Confession arose from a process of discernment by the WARC reflecting over almost a decade on a Reformed response to the glaring economic disparities experienced by members of several member churches. With progressive discussion and consideration arising from experiences in more contexts, the discernment grew to include ecological problems as well when delegates to the various theological consultations and Council meetings rightly considered the intersectionality of economic and political injustice with ecological ones. When it was formally announced at the 2004 General Council of the WCRC, it became the Reformed tradition's closest effort to theologically addressing the ecological crisis on a catholic level. Certainly, the Confession itself is neither perfect nor comprehensive to all issues pertaining to environmental and ecological destruction, and this reality might reflect how other issues of public concern, such as poverty or human rights, often take precedence ahead of environmental concerns. Nonetheless, ecclesia reformata est semper reformanda. ${ }^{3}$ The call to continually reform and re-engage theology in conversation with current challenges remains a critical dimension of Reformed identity. The Accra Confession, thus, will not be the final Reformed response to climate change, especially as the consequences of climate change become increasingly pronounced with changing weather patterns and elevating temperatures.

But the fundamental problem preventing a unified response to climate change is Reformed catholicity-how can a diversity of theological approaches and interpretations to climate change in the Reformed tradition find a ground to be reconciled so that a way forward to climate action can begin to coalesce? This study resourced the voice of Johann Baptist Metz to demonstrate how dangerous memories can assist in this reconciliation. It does this by grounding theology in the theological interruptions brought about by dangerous memories of suffering. Hence, even though there may be differences concerning what love looks like when applied to environmental problems, the way to harmonize the differences arrives by approaching those problems from the perspectives of those suffering most from the ravages of climate change, not from those occupying the commanding heights of economic, political, and military power. The Accra Confession, despite its imperfections, contributes powerfully to the task of formulating and constructing a concerted Reformed response to ecological destruction through its potentialities as an interrupter of the unsustainable ways of living as a society that we have taken as normative.

The Reformed conundrum surrounding the appropriate approach for addressing climate change theologically is reflective of how secular institutions such as the United Nations have addressed the issue concretely. Just as there is a lack of binding catholicity in the tradition that prevented a comprehensive and unified response to the ecological crisis, the necessity of ways to bind nations to an inter-national agreement such as the Paris Agreement have handicapped secular institutions and governments from 
pursuing a concerted way to address the matter. Using dangerous memory as a theological method can also inspire a new negotiating method whereby citizens from emissions-generating countries are made painfully and viscerally aware of how their consumption patterns have caused tremendous suffering for others elsewhere. Additionally, despite the secularity of such international organizations, the Accra Confession provides possibilities for recognizing how a powerful religious dimension exists in climate change discourses that must be addressed should concrete and ambitious progress on the issue be desired. The Accra Confession, then, not only provides hope to Reformed churches and the world that the Reformed branch of Christianity can be a helpful ally in promoting ecologically sustainable ways of living, but also provide the seeds for how differences can be negotiated so that all earthly creatures can, indeed, enjoy life in fullness.

Funding: This research received no external funding.

Conflicts of Interest: The author declares no conflict of interest.

\section{References}

World Communion of Reformed Churches. 2004a. The Accra Confession. Reformed World 55: 185-90. Available online: http://wcrc.ch/accra/the-accra-confession (accessed on 11 June 2020).

World Alliance of Reformed Churches. 2004b. Letter from Accra. In Accra 2004: Proceedings of the 24th General Council of the World Alliance of Reformed Churches. Geneva: World Alliance of Reformed Churches.

Ashley, J. Matthew. 2003. Interruptions: Mysticism, Politics, and Theology in the Work of Johann Baptist Metz. Notre Dame: University of Notre Dame Press.

Augustine of Hippo. 1996. Teaching Christianity (De Doctrina Christiana). Works of Saint Augustine I/11. Translated by Edmund Hill. Hyde Park: New City Press.

Augustine of Hippo. 2004. Expositions of the Psalms 121-150 (Enarrationes in Psalmos). Works of Saint Augustine III/20. Translated by Maria Boulding. Hyde Park: New City Press.

Barrett, Scott. 2008. Climate treaties and the imperative of enforcement. Oxford Review of Economic Policy 24: 239-58. [CrossRef]

Barth, Karl. 2017. The Christian Life. Translated by Geoffrey W. Bromiley. London: T\&T Clark. First published 2004.

Benjamin, Walter. 2007. Theses on the Philosophy of History. In Illuminations. Edited by Hannah Arendt. Translated by Harry Zohn. New York: Schocken Books, pp. 253-64. First published 1968.

Benzoni, Francisco. 2004. An Augustinian Understanding of Love in an Ecological Context. Quodlibet Journal. 6. Available online: https://web.archive.org/web/20170516172450/ (accessed on 11 June 2020).

Boisson de Chazournes, Laurence. 2008a. "Introduction to the Kyoto Protocol to the United Nations Framework Convention on Climate Change." United Nations Audiovisual Library of International Law. Available online: http://legal.un.org/avl/ha/kpccc/kpccc.html (accessed on 14 June 2020).

Boisson de Chazournes, Laurence. 2008b. "Introduction to the United Nations Framework Convention on Climate Change." United Nations Audiovisual Library of International Law. Available online: http: //legal.un.org/avl/ha/ccc/ccc.html (accessed on 11 June 2020).

Calvin, John. 2006. Institutes of the Christian Religion. Edited by John T. McNeill. Louisville: Westminster John Knox Press. First published 1559.

Chryssavgis, John. 2007. Ecumenical Patriarch Bartholomew: Insights into an Orthodox Christian Worldview. International Journal of Environmental Studies 64: 9-18. [CrossRef]

Coglianese, Cary. 2019. Pledging, Populism, and the Paris Agreement: The Paradox of a Management-Based Approach to Global Governance. Maryland Journal of International Law 34: 139-80.

Hewitt, Marsha. 1994. The Redemptive Power of Memory: Walter Benjamin and Elisabeth Schüssler Fiorenza. Journal of Feminist Studies in Religion 10: 73-89.

Johnson, Elizabeth. 1998. Friends of God and Prophets: A Feminist Theological Reading of the Communion of Saints. New York: Continuum.

Leal-Arcas, Rafael, and Antonio Morelli. 2018. The Resilience of the Paris Agreement: Negotiating and Implementing the Climate Regime. The Georgetown Environmental Law Review 31: 1-64.

Marsden, John. 2012. The Political Theology of Johannes Baptist Metz. The Heythrop Journal 53: 440-52. [CrossRef] 
Metz, Johann Baptist. 1981. The Emergent Church: The Future of Christianity in a Postbourgeois World. Translated by Peter Mann. New York: Crossroad.

Metz, Johann Baptist. 1999. Love's Strategy: The Political Theology of Johann Baptist Metz. Edited by John K. Downey. Harrisburg: Trinity Press International.

Metz, Johann Baptist. 2007. Faith in History and Society: Toward a Practical Fundamental Theology. Translated by J. Matthew Ashley. New York: Herder \& Herder.

Möller, Ulrich. 2005. The Accra Confession and its ecclesiological implications. Reformed World 55: 202-13.

Opočenský, Milan. 1997. Address of the General Secretary. In Debrecen 1997: Proceedings of the 23rd General Council of the World Alliance of Reformed Churches.. Geneva: World Alliance of Reformed Churches.

Ortega, Ofelia. 2009. Communion and justice, contribution to the global dialogue. Paper presented at the World Communion of Reformed Churches Conference, Johannesburg, South Africa, September 3-7.

Park, Seong-Won. 2004. A journey for life: From Debrecen to Accra and beyond. Reformed World 55: 191-201.

John Paul II, Pope. 1990. Message for the Celebration of the World Day of Peace. Vatican City. January 1. Available online: https://bit.ly/2H6uFHS (accessed on 8 February 2020).

Reynolds, Amy. 2014. Free Trade and Faithful Globalization: Saving the Market. Cambridge: Cambridge University Press.

Sheerattan-Bisnauth, Patricia. 2008. Confessing Faith Together in the Economy: The Accra Confession and Covenanting for Justice Movement. International Review of Mission 97: 233-44. [CrossRef]

Smit, Dirk. 2009. Theological Assessment and Ecclesiological Implications of the Accra Document 'Covenanting for Justice in the Economy and the Earth'-Tentative Comments for Discussion. In Globalisation: The Politics of Empire, Justice, and the Life of the Faith. Edited by Allan Boesak and Len Hansen. Stellenbosch: SUN Press.

Smith, J. Warren. 2016. Loving the Many in the One: Augustine and the Love of Finite Goods. Religions 7: 137. [CrossRef]

Song, Choan-Seng. 2004. From the Ends of the Earth: Address of the President. In Accra 2004: Proceedings of the 24th General Council of the World Alliance of Reformed Churches. Geneva: World Alliance of Reformed Churches, p. 2004.

Urpelainen, Johannes, and Thijs Van de Graaf. 2018. United States non-cooperation and the Paris agreement. Climate Policy 18: 1-13. [CrossRef]

Van der Borght, Eduardus. 2008. Reformed Ecclesiology. In The Routledge Companion to the Christian Church. Edited by Gerard Mannion and Lewis S. Mudge. London: Routledge, pp. 187-201. 